\title{
Effect of Sonic Vibration on the Property and Potency of Lepromin.
}

\author{
MASAhide ABE and Tetsu NAKAYAMA \\ National Institute for Leprosy Research \\ Noboru TACHIKAWA and Kazuko OKAMURA \\ National Leprosarium Tama Zensho-en
}

When the standard lepromin was treated with the sonic vibration (9.5 kilocycle per sec.), the corse tissue fragments were dispersed in fine particles, and at the same time the number of leprosy bacilli diminished exponentially. Under the conditions of the experiment, about half of the bacilli was destructed within 5 minutes. The complement-fixing ability of the lepromin with leprous serum was, however, increased by the sonic vibration showing that the active substance was not destroyed by this treatment. Comparison of potency tests on leprosy patients gave the results that the lepromin sonic-vibrated for 30 minutes elicited weaker early reactions than the untreated standard lepromin, while there was no significant difference between them with respect to the late reactions. Consequently, it is considered that the late reaction may be caused not only by the intact leprosy bacilli but also by the mechanically destructed bacilli.

$$
\begin{aligned}
& \text { レプロミンの性状並びに力価に対する音波の作用 } \\
& \text { 阿部正英 中山哲（国立多摩研究所） } \\
& \text { 立川昇岡村和子 (多磨全生園) } \\
& \text { (受付, } 6 \text { 月 } 8 \text { 日，1963) }
\end{aligned}
$$

レプロミン（光田抗原）による皮内反応の実施に際し て, 誰れもが経験する不安は, 注射器内で粗い粒子が 沈澱するために，注射量が不平等になる恐れであろう。 これを解消する一つの手段として，レプロミンと音波 を作用させ，粗い組織成分を分散させる試みを行った。 すでに，北野ら は超音波によりレプロミンの力価が 低下することを報告している。音波の作用は超音波の それと幾分異るとはい光，癩菌を破壊することは中山 及び林 ${ }^{2}$ の報告にも見られるので，音波の作用により レプロミンの力価がどのような影響を受けるかを確め るとともに, 瀬菌の破壊を最小限に留め組織成分の分 散をよくする如き条件を見出すことを試みた。

\section{材料並びに方法}

1）使用抗原この実験に用いたレプロミンは昭
和35年 7 月作製の lot 12 であり, これの菌数は $1 \mathrm{~m} \ell$ 中 に約 1 億 5 千万であった。

2) 音波処理 音波発生装置（久保田製作所）を 用い, 容積約 $100 m \ell$ のステンレス容器内にレプロミン を約 $10 m l$ 入, 容器の周囲を流水で冷却しながら, 出 力 $200 \mathrm{~W}, 9.5$ キロサイクル/秒の音波を作用させたの ち, 内容をガラス小瓶に移し密封して保存した。音波 作用時間は $5,10 ， 30 ， 60$ 分の 4 種類を試みた。

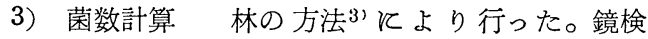
そさいし, 定型的な癩菌のみを数元, 菌体崩壊物と 思われる抗酸性顆粒は除外した。また音波による菌塊 (Globi) の大きさ並びに数の減小にも注意を払った。

4）補体結合反応無処理並びマ音波処理レプロ ミンを抗原とし，癩患者混合血清による補体結合反応 を, Kabat and Mayer の定量的方法 '“' 飞多少の改変 
を加えて行った。すなわち， $\mathrm{Ca}$ “拉よび $\mathrm{Mg}$ を加兄 た Veronal 䌅衝食塩水 $(\mathrm{pH} 7.4)^{5)}$ を用いて, 上記レ プロミンの 8.5 倍希釈液 $1 \mathrm{~m} \ell, \quad 56^{\circ} \mathrm{C} 30$ 分加温癩血清 10 倍希釈液 $1 \mathrm{~m} \ell$, 抢よび標準溶血系統飞より $50 \%$ 溶血法 で測定した補体（モルモット血清）の50単位を混和し， 全量を $5 \mathrm{ml}$ として, $37^{\circ} \mathrm{C}$ 1 時間招いたのち, 混合液 の一定量を適当飞希釈して, 標準溶血系統により残存 補体単位を測定し，50単位加差引いて補体結合単位 を求めた。さら飞, 抗原並び癩血清単独により不活 化される補体量を同様飞測定して，それらを上記の値 から差引いた残りを真の補体結合単位とした。な扔, 希釈抗原を $20,000 \mathrm{rpm} 1$ 時間遠心沈測して得た透明な 上清について，上記と同じ条件で補体結合反応を行っ
た。

5) レプロミン反态多摩全生園の患者85例（癩 腫型66, 非癩腫型19)飞ついて，無処理レプロミン と音波30分処理レプロミンとによる早期並びに晚期反 忘の大きさを常法通りに計測した。注射部位差を除く ため, 約半数の患者で左右前膊に注射するレプロミン の種類を入れかえた。

成 績

1）音波作用によるレプロミンの性状の変化

音波を $5 ， 10 ， 30 ， 60$ 分作用させたレプロミン中の 菌数を計算し，音波作用時間と菌数の減少との関係を 求めた結果を困 1 亿示す。

Table 1. Effect of sonic vibration on the number of globi in standard lepromin.

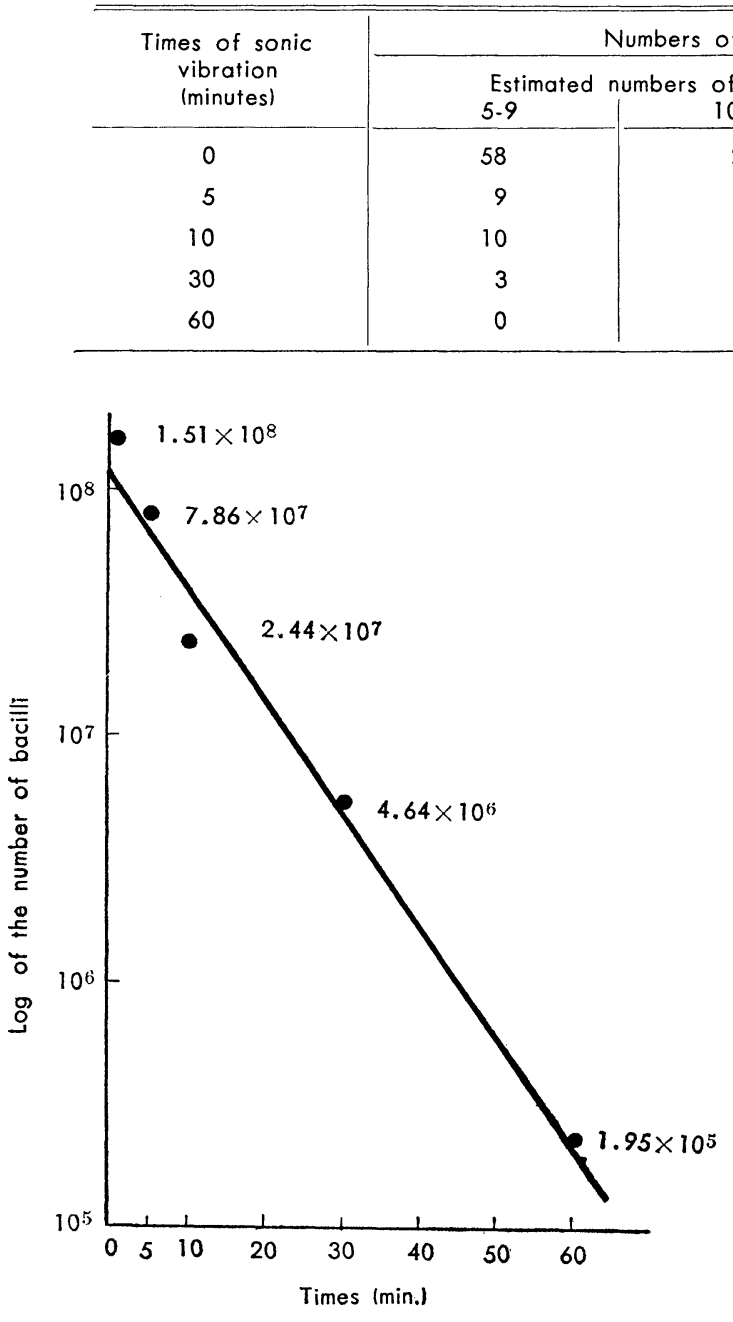

Fig. 1. Effect of sonic vibratiou on the number of bacilli in standard lepromin.

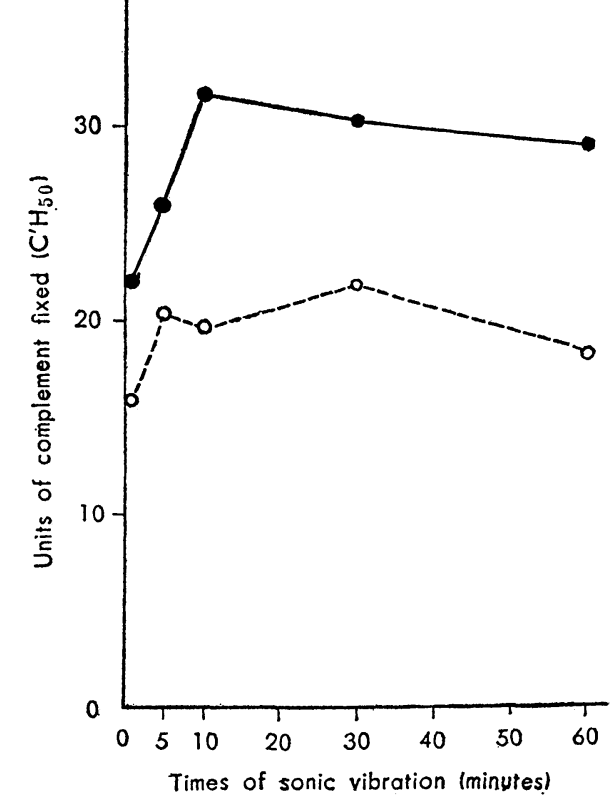

Fig. 2. Quantitative complement-fixation reactions of leprous sera with the lepromin and its supernatant treated with the sonic vibration in various times. - Sonic-vibrated lepromins diluted in 1:8.5 - Supernatants of the aboves after centrifug ng 20,000 rpm. ior 1 hour. 
菌数の対数と音波作用時間との間には，明らかに直線 関係が認められた。音波 5 分の作用により，菌数はも とのレプロミンの約 $1 / 2$ となり，30 分の作用により約 1/30亿減少する。また菌塊（Globi）の数と大きさる, 表 1 亿示すごとく，著明な減少を起す。他方組織成分 の粗大な粒子は音波 $\mathbf{5}$ 分の作用ではいくらか残存する が，10分以上作用させた場合飞はほとんど消失した。

音波処理レプロミン招よびその遠沈上清を抗原とし， それと癩患者血清との補体結合能力をしらべた結果を 図 2 亿示す。抗原と抗体の量は一定であるとかかわら ず，音波作用により補体結合単位の増加が起るが，こ の増加は音波10分処理で最大となり，30分以上作用さ せるとやや減少する傾向が見られた。音波処理抗原 を20,000 rpm 1 時間遠沈して，粒状成分を完全飞除去 した上清を用いた場合には，補体結合単位はかなり低 下し，音波処理による增加はさほど顕著でなかった。

2）音波作用飞よるレプロミン力価の変化

音波を30分作用させたレプロミンと無処理のものと 飞よる皮内反応の比較試験を行った。図 3 は早期反応 の相関を，図 4 性晚期反応の相関をあらわす。これら

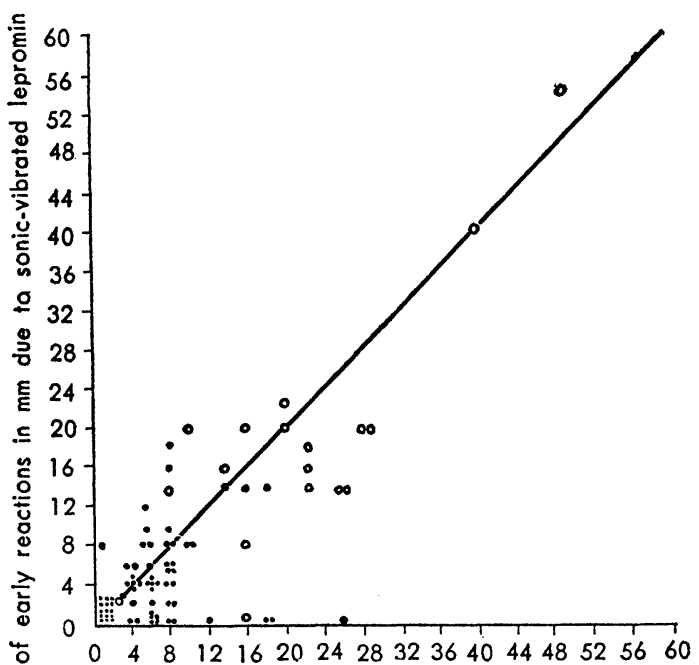

. Siz̀ of early reactions in $\mathrm{mm}$ due to standard lepromin

Fig. 3. Correlation, by sizes of early reactions, between standerd and sonic-vibrated lepromins.

- Lepromatous cases oNon-Lepromatous cases

の図から力価差があるか否かを直観的に知ることは 困難なので、推計学的に検討するために，無炕理レプ ロミンと音波処理したものとの反応の大きさの差を各 患者について調へ，差の平均值を０とみなしうるか否 かを調べた。その結果, 早期反応飞执いては差の平均值 は2.14となり，これは $1 \%$ 以下の危險率で有意差とい うことができるが，晚期反応飞括いては差の平均值は 0.588 であり，これは有意差であるとはいえなかった。
Fig. 4. Correlation, by sizes of late reactions, between stendard and sonic-vibrated lepromins.

- Lepromatous cases o Non-lepromatous cases

\section{考察}

レプロミン反応の本態に関しては，な抒疑問の点が 多いが，Fernandez の早期反応はツベルクリン反応 と同様瀬菌水溶性成分（恐らく蛋白）飞上る迤延型 アレルギーであり, 光田晚期反応は癩菌体そのものが 主役を演ずる細胞性免疫反応であるという解釈 ${ }^{6}$ が広 く認められている。癩結節からクロロホルムその他の 有機溶媒により分離した癩菌浮遊液では早期反応は起 るが晚期反応が弱いこと $7 .{ }^{81}$, 北野ら ${ }^{11}$ の超音波処理 レプロミンが晚期反応の减弱を起すととなどから, $W^{2}$ (d) $^{7}$ は intact な癩菌の存在が晚期反応飞不可缺 であると考光ている。

我々が用いた $9.5 \mathrm{KC}$ の音波には，組織成分を分散 させるのみならず，癩菌をる破壊する作用があるので， レプロミンの音波処理により早期反応は増強され，晚 期反応は減弱すると予想される。しかし事実は全く逆 であり，音波 30 分処理により癩菌数はもとの約 $1 / 30$ V 減少し, in vitro 飞招ける補体結合抗原性は処理前飞 比べとやや増加したにもかかわらず，早期反応には 明らかな減弱を起し，晚期反応にはほとんど変化を生 じなかった。これらの事実は次のように解釈しうる。 音波の作用により，癩菌体から水溶性成分が遊離する 之同時に，不溶性の菌体並びそ組織成分も細かく分散 されるので, その表面に水溶性成分の吸着が起り，遊 離の状態のものはかえって少なくなるために，早期反 応が弱くなるのであろう。図 2 亿示した如く，音波処 理によりレプロミンの補体結合量は増加するが，高速 
遠心沈測飞より粒状成分を除き，水溶性分のみを抗原 とした場合には, 補体結合量の増加がさほど顕著でな いことは，上述の如き分散状態の変化を示唆するよう 飞思われる。他方, 晚期反応は細胞性の反応であるか ら, 分散状態の変化した抗原成分でも, intact な癩菌 と同樣飞細胞内にとりこまれるので, 反応の強さと影 響を及ぼすととはないと思われる。あるいは，細胞内 そ入りにくいような粗い粒子（ないし菌塊）が分散さ れることにより, 細胞反応が促進される可能性も考兄 られる。いずれとせよ，晚期反応には intact な癩菌 が必要であるという説は我々の実験結果から否定しう るょうと思われる。北野らの超音波処理の条件は不明 であるが，恐らく超音波の酸化促進作用注り，抗原 の活性が失われたのであろう。9.5KC の音波の作用 は超音波より緩慢であり, 酸化も起りにくいことは, in vitro 飞搁ける抗原性が音波60分作用後飞る保持さ れていることからも明らかであるう。

音波の作用により，レプロミン中の癩菌数が指数曲 線的減少を起すことは, この反応が一次反応であるこ とを示す。図 1 の直線の傾斜すなわち菌破壊速度恒数 は，さき飞中山，林 ${ }^{2}$ が結節からある程度集菌した人 癩菌括よび単癩菌について得られた值にほぼ等しく, 従って組織成分の有無飞関係なく癩菌の破壊が進行し, その半減期は拓上そ 5 分であると推定される。他方, 組織成分中の粗大な粒子を完全飞分散させるには， 5 分以上の作用時間が必要であったので, 我々が当初の 目的とした組織成分のみを分散させる如き音波処理条 件を見出すことは失敗であった。しかし，音波により 癩菌数が減少しても, 晚期反応の力価飞変化は起らぬ ことがわかったので, 粗い組織成分を分散させること は，レプロミン注射量の不均一をなくすためには役立 つようと思われる。

\section{総括}

レプロミンに $9.5 \mathrm{KC} /$ 秒の音波を作用させると, 粗 い組織の成分分散が起ると同時に，癩菌数沉も指数的
減少が起り，用いた条件下では 5 分で菌数は半減した。 しかし，レプロミンと癩患者血清とによる補体結合単 位は, レプロミンの音波処理により増加を起した。音 波30分処理レプロミンと無処理のものとを用いて，癩 患者飞皮内反応の比較試験を行った結果, 早期反応の 大きさ音波処理により減少を起すが，晚期反応の大 きさは両者間に有意差を示さなかった。従って、レプ ロミン晚期反応は完全な癩菌体の存在を不可缺とする ものではなく，機械的破壊された癩菌によっても起 りらるょうと思われる。

\section{文献}

1）北野博一, 井上猛夫，林文雄：超音波ワクチン飞 よる光田氏反応（抄） レプラ，12，211 (1941)

2）中山哲，林喜久夫：音波䏓よ大腸菌，結核菌， 癩菌の破壊沉ついて，日本細菌学雑誌 15, 587(1960)

3）林喜久夫：癩菌の菌数計算法招よびそれを使って 算定された各種臟器中に打ける瀬菌数, レプラ 28 , 13 (1959)

4) Kabat, E. A. and M. M. Mayer: Experimental Immunochemistry. C. C. Thomas Publisher, Springfield, Illinois, USA (1948)

5) Mayer, M. M. et al: The activating effects of magnesium and other cations on the hemolytic function of complement, J, Exp. Med. 84, 535 (1946)

6) Transactions of the 7th International. Congress of Leprology, p 463 (1958)

7) Wade, H. W: WHO Expert Comittee on Leprosy: Second Report (1959) (邦訳, レプラ, 29, 250(1960)

8) Wade, H. W. et al: Lepromin vs purifed bacillus suspension. II. Comparative tests with a purified bacillus suspension, Internat. J. Leprosy, 30, 27 (1962) 